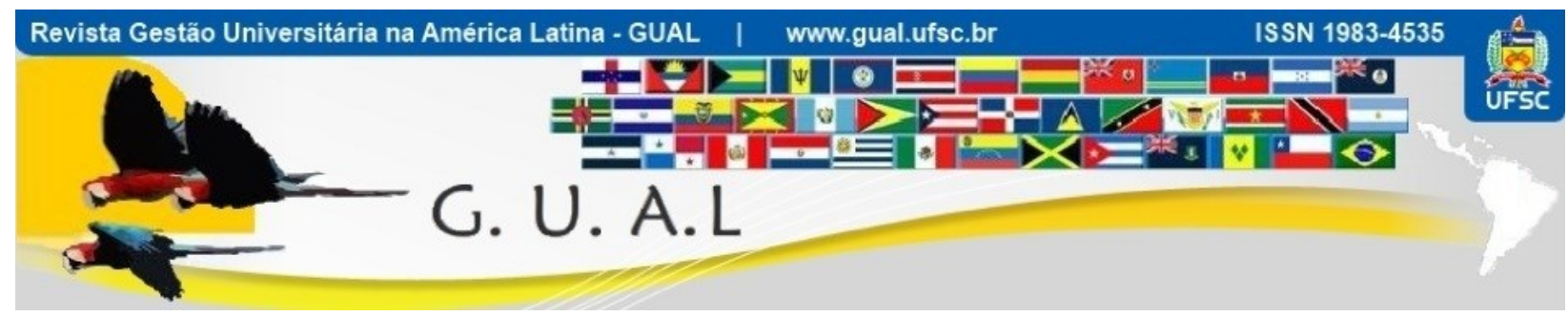

DOI: http://dx.doi.org/10.5007/1983-4535.2015v8n4p134

\title{
THE MASSIFICATION PROCESS IN CHINESE HIGHER EDUCATION
}

O PROCESSO DE MASSIFICAÇÃO DA EDUCAÇÃO SUPERIOR CHINESA

Danilo de Melo Costa, Doutorando

Universidade Federal de Minas Gerais - UFMG

danilomct@gmail.com

Qiang Zha, PhD

University of Toronto

qzha@edu.yorku.ca

Recebido em 05/dezembro/2014

Aprovado em 05/abril/2015

Sistema de Avaliação: Double Blind Review

Esta obra está sob uma Licença Creative Commons Atribuição-Uso. 


\begin{abstract}
This paper demonstrates the massification process in higher education using as reference China, which reached in a few years the largest university system in the world. To do this, we present in the theoretical reference the Government intervention and its economic responsibilities, the main challenges of global higher education and the effects of globalization on this level of education. As regards the methodology, this study is designed on the principles of explanatory research, with qualitative approach. Data were collected through documentary and bibliographic research, and subsequently analyzed and interpreted to record the findings that were correlated with other data collected. This research shows at its end how was the expansion of Chinese higher education, which was a elite system and became a mass system, becoming a reference for other nations that also seek to expand this educational level.
\end{abstract}

Keywords: Higher Education. China. Massification. Expansion. Public Policies.

\title{
RESUMO
}

O presente artigo demonstra o processo de massificação da educação superior utilizando como referência a China, que conseguiu se consolidar, em poucos anos, como o maior sistema universitário do mundo. Para tanto, são apresentados no referencial teórico a intervenção estatal e suas responsabilidades econômicas, os principais desafios da educação superior mundial e os efeitos da globalização sobre este nível de educação. No que se refere à metodologia, o presente estudo é delineado sobre os princípios de uma pesquisa explicativa, de abordagem qualitativa. Os dados foram coletados mediante a pesquisa documental e bibliográfica, e posteriormente analisados e interpretados, para realização de fichamentos dos achados que foram correlacionados com os demais dados coletados. A presente pesquisa apresenta, ao seu final, de que forma ocorreu o expansão da educação superior chinesa, que passou de um sistema de elite e se tornou um sistema de massa, se tornando uma referência para outras nações que buscam também a expansão deste nível educacional.

Palavras-chave: Educação Superior. China. Massificação. Expansão. Políticas Públicas. 


\section{INTRODUCTION}

Education in China has always been seen as something critical to the country's progress. One of the biggest cultural traditions, Confucianism, has emphasized already the education in the development process. Between the old classics, can be found phrases like "To develop a nation, education should come first" or "A man without education will not be an ethical and well informed man." (MIN, 2004).

Over the past decades, when China decided to open up to the world, China's leaders have become aware of the importance of higher education in order to ensure a workforce with more quality and also for conducting cutting-edge research (HAYHOE and ZHA, 2004). This priority for education, especially higher education, has helped in the training of more skilled human resources and generated scientific and technological inventions that are absorbed more easily (MIN, 2008).

Over the past 20 years, the world has witnessed a tremendous growth of China's GDP. According to Professor Zhou Zhong, from the education department of Tsinghua University, one of the most prestigious universities of China, investment in education is the base of support for the success of the Chinese economy (NAOE, 2012).

What is behind the success of Chinese higher education? To Zha and Hayhoe (2008) is the "visible hand" of government, which employed a number of instruments and policies to promote a massification of higher education enrollments led by the Government. Furthermore, the authors argue that China starts to create a model emergent from the University, coordinated with plans for national and local development, giving a great support to institutions and academics that are reference in production that can meet the needs of the country. "Post-growth" policy initiatives also represent an effort to growth to be qualitative, combining the interests of the Central government, local governments and universities.

To better understand this growth, the paper seeks to answer the following research questions: what makes the principal driving force behind massification of Chinese higher education? What challenges face Chinese higher education in the post-massification era?

From this information, this paper presents as has happened this expansion, which can serve as a benchmark for other nations seeking to expand their indicators with regard to higher education, once China now has the largest higher education system in the world. 


\section{THEORETICAL REFERENCE}

This section begins by describing the role of the government, especially its main economic responsibilities, something essential to expand higher education in a nation. Subsequently, the study presents the challenges of global higher education, with focus to North America, Europe, South America and Asia. Finally, we explained the effects of globalization on higher education, causing a great need for investment.

\subsection{GOVERNMENT INTERVENTION AND THEIR ECONOMIC RESPONSIBILITIES}

The Government is a central agent to meet the expectations of society, given its interference in economic, political and social activities, through well-established public policy. This intervention is possible because the government presents itself as a regulatory body, seeking to do a promotion of development, a fair distribution of income, maintain the stability of the economy, and also provide public goods and services to society. Development models with government intervention have the intention to positively influence the orientation of elements in the short and long-term the dynamics of a nation. Among all the actions of government responsibility, some are highlighted: safety; employment; health; and education. These actions aim to reduce violence, social inequality and improve the quality of life (MATIAS-PEREIRA, 2006).

However, the modern capitalist economy is not only controlled by the government economic system, it also suffers influences of the market, which often outline the actions of the society (GUERREIRO RAMOS, 1981). Thus, the role of keeping the economy on a sustained growth shall be the responsibility of both systems, public and private, because they are in the same sociopolitical dynamics. Frey (2001) complements this reasoning when he argues that government intervention is crucial in order to minimize or eliminate the adverse effects of economic growth.

Tax collection shall then be the main tool in order to maintain the proper balance of the public system by the growth of the private system (LONG, 1984). This tax collection, which marks a strictly budgetary function of government, is the main influence of the government for economic activities by means of conducting monetary policy, management of state-owned enterprises, private enterprises regulations, policies for the price controls and inflation, among others. 
In addition, the Government must also play an important role in opening trade, technological innovation, communication and promotion of national consensus (MATIASPEREIRA, 2006; IGLESIAS, 2006), something that to Lerda, et. al (2005) should be performed with greater efficiency and effectiveness, since activities are responsible for providing the provision of higher quality service to the population.

Public finances, by the power of the government, seeking to finance public goods and services that people can not buy in small quantities, such as education, security, public health, justice, among many others. This funding comes from taxes, productive activities of the Government and credit or loans (MATIAS-PEREIRA, 2006). The diversification of these objectives of government intervention in economic activity generates various possibilities of conflict and requires a great deal of planning and coordination.

These objectives can be grouped into 4 categories:

- Meeting the needs of society;

- Maintenance of Economic Stability;

- Economic Growth;

- Improvement in income distribution.

The government intervention in developing countries such as Brazil, China, India, among others, is often based on ideological reasons, or because the private sector was not able to make the necessary investments for the development of a sector (GIAMBIAGI and ALÉM, 2001).

Finally, to Silva (2005), government intervention is directly linked to the creation and implementation of public policies in any segment. Thus, measuring this correlation becomes a priority to establish efficient distribution of public resources, which has a proportionately smaller increase than the needs for public services. Public policies should meet and funding issues that go beyond the main reason for which they were developed, for example, a public policy that aims to increase access and permanence in higher education can also affect economic issues (more skilled labor), social (lower unemployment and therefore criminality), among several other factors that concern the nations in recent decades.

\subsection{CHALLENGES OF HIGHER EDUCATION WORLDWIDE}

At the end of the first decade and the beginning of the second decade of this century, several nations, especially the developed nations, have faced one of its greatest financial crises. Economically healthy continents, such as North America and Europe are the most 
affected, especially the United States, which shall have its hegemony threatened by China (SAWAYA, 2009). That situation makes these continents start to rethink a number of cyclical and structural changes to retake the best growth rates.

Experiencing unwanted situations, some instruments are now considered key to improving economic indicators, including higher education, which is responsible for various factors that have direct impact to the performance of the economy, such as:

i) Training of skilled labor, which causes direct impact on productivity and therefore the job creation;

ii) Discoveries of innovations, which although marketed may also assist in the economic progress of countries and in job creation; and

iii)Creation of new business and maintaining existing business, by empowering entrepreneurs;

Factors such as these are responsible for that nations start to give even more attention to higher education, such as the United States. The respective nation begins to worry not only in generating technological innovations as well as how to sell the innovations that has been developed to achieve favorable economic results. This concern is due to the speed with which Asians are reproducing such innovations and then selling them to the rest of the world, something easily possible after globalization (ERNST, 2005).

In Europe, higher education also becomes a major instrument. The main adversity faced by countries are the high rates of unemployment, something that can be minimized with the creation of skilled labor, influencing productivity, as well as training of entrepreneurs. Entrepreneurship results in the creation of employment, something that is crucial to the economic performance of European countries in the coming decades (EUROPEAN COMISSION, 2011).

On the other hand, continents like South America and Asia, especially countries Brazil, China and India, are living a moment of progress, because they are considered the major emerging economies of the world. The crisis that is affecting developed countries helps in the growth of emerging countries, who understood the importance of higher education and has gradually improved its indicators. Investments in education have a direct impact on innovation, which can be seen in oil exploration, of minerals, production of software or even electronics, things that are responsible for the good results of the countries.

The information mentioned above shows the relevance of the effects of globalization worldwide, with a deep impact on education (especially higher education) and it's financing. 


\subsection{EFFECTS OF GLOBALIZATION ON HIGHER EDUCATION}

Based on the globalization, there is a worldwide need for higher levels of education, resulting in a large increase in demand and access for students who pursue post-secondary courses (ILON, 2010).

Analyzing the developed countries, Lazerson (2010) argues that globalization was responsible for promoting competition for financial resources between countries and universities, promoting changes in their funding. These resources were obtained through the scientific and technological innovation through the generation of patents, given that they represented real results to market. Additionally, students began to seek higher education courses in accordance with the shortage of skilled labor, causing both economy and market lead offers of higher education.

This globalization from scientific and technological developments is now called "economic globalism", since it tries to produce more capital accumulation and has strong influence of capitalism. The economic globalism has features like free markets, competitiveness, open communication, individualism, deregulation and privatization of the public sector (TÜNNERMANN BERNHEIM, 2010).

This "new globalization" then goes on to influence higher education, which should suit this new global reality, aiming to produce knowledge that is commercial, affecting traditional academic activities, because began to be guided by the requirements of applicability and market value.

To Didriksson (1993), is explicit the economic role that has higher education, since it has a special relationship with the production of knowledge related with industry. The author complements saying that many of the knowledge produced are intended to provide input to economic production, featuring in a close relationship.

From the structural changes described earlier, Carnoy and Rhoten (2002) describe that the financing of higher education began to receive a large investment from the private sector, especially in countries like the United States and the United Kingdom (decreasing the financial support from the Government). On the other hand, the authors argue that the Government's participation in the financing of higher education in East Asian countries has increased considerably, demonstrating a firm commitment to improving the quality of higher education institutions, which came to be seen as a major factors for the progress of countries. 
As a result of these investments, a third of the top universities in the world is located in the Asia Pacific region, due to a major intervention of the government in emerging countries from Asia (CARNOY; RHOTEN, 2002). Countries like Taiwan, South Korea and especially China are increasing the funding for their universities with the aim of increasing the number of universities with global prestige.

Ilon (2010) presents the results of these countries are amazing, when it finds that Asia has formed nearly twice as engineers that Europe, professional area that has a certain lack of skilled labor, representing the important role that education has played in the top world economies.

\section{METHODOLOGY}

The process of structuring the paper was based on studies related to the topic, creating a theoretical framework grounded in major changes occurring in higher education in China, focusing on their policies and the main results from the beginning until nowadays. The aim of the respective structure has been the studied object by means of viewpoints, features and angles of the problems in different ways, establishing connections in order to get the state of the art (MINAYO, 1998).

The research presents the form of a qualitative approach because, as the statement from Richardson (1999), tries to interpret the object in terms of its significance, especially for an appropriate way to understand the aspects of a social phenomenon.

The delimitation of the research was based on the choice of an intentional sample. This type of sample is suggested in research that have as purpose understanding the case studied in greater depth (SELLTIZ, et. Al. 1975). So, we decide to study China among 193 countries in the world (UN, 2013). The choice of that country happens because it is a country of continental dimensions and performed a real revolution in higher education in recent years.

The data were collected through documental research, which is a source of data collection from documents (contemporary or retrospective), but scientifically classified as authentic (MARCONI and LAKATOS, 1990). From then on, were used to collect data from China documents, such as management reports relating to government policies over the past 10 years, decrees, performance management policy report, statistical data related to public policy and data from the Ministry of Education. In addition, to ensure the representativeness of the research, a bibliographical research through material already developed and published on the topic to be researched was performed. The bibliographical research included the 
reading, analysis and interpretation of single publications, newsletters, newspapers, magazines, books, articles, dissertations and doctoral theses from around the world, especially publications of the respective countries studied (GIL, 1995).

Finally, the data from both documental research as the bibliographical research were submitted to a review, to establish a plan of analysis and interpretation of the collected material, performing records of the items that were correlated with other data collected.

\section{THE MAIN PATHWAYS OF CHINESE HIGHER EDUCATION TO ACHIEVE THE MASSIFICATION}

This section aims to contextualize the paths of Chinese higher education in order to stop being an elite system going to become a mass system (TROW, 2006). To this end, we present the changes in higher education, which led to the first major expansion. From then on, we highlight the policies and the massification of Chinese higher education, which led to the second major expansion, making China the country with the largest educational system in the world.

\subsection{CHANGES IN THE FINANCING OF HIGHER EDUCATION - THE FIRST GREAT EXPANSION}

During the socialist period (1949-1978), conducted by Mao Tse-Tung, the source of funds for education was unique, depending only on the government budget, particularly the central government, however, there was a great disparity between the resources available to basic education versus higher education, the second being prioritized. At this time, beyond the enrolled students do not pay any fees the government also offered support for the expenses of the students. This policy resulted in institutions of basic education in poor conditions, lack of resources and infrastructure unavailable. According Houkai (1999), in 1981, between all space used for primary and secondary schools, $15.91 \%$ were unusable.

For Johnstone (1986), the situation faced by education in the socialist period was responsible for starting an overall reform of the educational system from the 80s. Regarding the financing of education, there was the establishment of a new mechanism aimed at better distribution of funds, which would be fundamental to education reform, for this reason, in 1986, the government defines the possibility of raising funds for education through "multiple channels", something that would be applied not only in higher education as well as in basic education, especially for rural areas. With this initiative, local governments would be 
authorized to collect surcharges that were intended primarily to compulsory education, based on the total sales of agriculture and of rural and municipal enterprises at levels previously defined by provincial governments. Subsequently, the State Council determined that should also be paid the urban educational surcharges, which started at $1 \%$ in 1986 , rising to $2 \%$ in 1990 and finally $3 \%$ in 1993 . This measure directly affects individuals who paid fees of products, income tax and taxes on business (ZHANG, 1993).

Another important initiative for higher education dates back to 1983, when this modality was divided into two segments: Regular higher education and adult higher education. The first included all conventional and polytechnics universities, the second included the universities by television programs, by correspondence, specials and evening programs, besides the universities of workers. The financing of the polytechnic courses and adult education were from World Bank projects. At this time, there were 2,355,000 students enrolled divided into 860 regular institutions of higher education and 1,191 higher education institutions for adults (WORLD BANK, 1986).

Continuing with the new reform, in 1985 the higher education institutions were authorized to admit students outside the local plan of enrollments, since they would finance themselves or be funded by some company. Based on this initiative, beginning in 1989, the country began to charge a portion of the inscription and several other academic fees for students who entered at higher education institutions (WORLD BANK, 1997). This fundraising through various channels made to diversify the sources of funding for education.

From then on, the new reform could increase the number of institutions and the student body, but began to face a new dilemma, the concentration of higher education institutions in the urban areas of the provinces. In this first stage of massification, society did not achieve equal opportunities, as can be seen in Table 1: 
Table 1 Students registered for population of 10,000 inhabitants (1990)

\begin{tabular}{|c|c|c|}
\hline Province & Urban Area & Rural Area \\
\hline Beijing & 24.62 & 3.53 \\
\hline Tianjin & 15.08 & 7.32 \\
\hline Hebei & 11.84 & 3.38 \\
\hline Shanxi & 18.5 & 3.7 \\
\hline Inner Mongolia & 9.23 & 4.81 \\
\hline Liaoning & 10.74 & 6.06 \\
\hline Jilin & 13.21 & 4.59 \\
\hline Heilongjiang & 9.32 & 3.47 \\
\hline Xangai & 15.81 & 6.45 \\
\hline Jiangsu & 9.87 & 4.84 \\
\hline Zhejiang & 10.47 & 3.88 \\
\hline Anhui & 12.82 & 2.46 \\
\hline Fujian & 20.7 & 4.05 \\
\hline Jiangxi & 17.93 & 2.23 \\
\hline Shandong & 12.01 & 3.28 \\
\hline Henan & 13.09 & 2.65 \\
\hline Hubei & 9.1 & 5.34 \\
\hline Hunan & 17.71 & 2.01 \\
\hline Guangdong & 10.04 & 4.06 \\
\hline Hainan & 23.67 & 3.46 \\
\hline Guangxi & 14.95 & 1.79 \\
\hline Sichuan & 12.08 & 2.42 \\
\hline Guizhou & 20.98 & 1.4 \\
\hline Yunnan & 24.98 & 1.85 \\
\hline Tibet & 32.24 & $0.09 *$ \\
\hline Shanxi & 18.46 & 3.05 \\
\hline Gansu & 18.26 & 2.95 \\
\hline Qinghai & 26.02 & 2.41 \\
\hline Ningxia & 23.54 & 5.84 \\
\hline Xinjiang & 18.98 & 3.48 \\
\hline Average & 13.75 & 3.23 \\
\hline
\end{tabular}

Source: $\mathrm{Wu}$ (2006, p. 18), adapted by the author.

* Note: Tibet is a special area, it has its own cultural and religious traditions.

To Wei (1999), becomes a challenge and a great necessity for the central and provincial governments balance the interprovincial educational finance by the transfer of funds due to such disparity.

Even with the challenges presented, the World Bank report about the reform of higher education showed that the results were very good, due to the previous situation experienced by the country. According to the report, higher education rose from 2,335,000 (1986) to $5,150,000$ (1994). If delimiting the regular higher education, the increase was $1,207,000$ 
(1986) to $2,798,000$ (1994), with $77 \%$ of students were enrolled in regular higher education institutions and 3\% in polytechnics. For adult higher education, the increase was $1,288,000$ (1986) to 2,252,000 (1994), divided in correspondence and evening programs offered by regular universities; Universities in television and radio; in schools for workers and peasants; in pedagogical colleges; and colleges of independent correspondence (WORLD BANK, 1997).

The same World Bank report shows that a change in funding was also observed, caused primarily by the increase in revenues generated by universities, since there was a reduction in government funding. In 1978, the fund of higher education was composed of $96 \%$ of government funds in 1990 , it was $87.7 \%$, decreasing to $86.9 \%$ in 1991 and further to $81.8 \%$ in 1992 . This shows that universities increased their revenue generation to cover the missing government amounts.

Finally, it was from the twenty-first century that the process of massification of Chinese higher education happened, becoming the largest higher education system on the planet.

\subsection{POLICIES AND THE MASSIFICATION OF CHINESE HIGHER EDUCATION - THE SECOND GREAT EXPANSION}

In 1993, the document entitled "Outline for Educational Reform and Development in China" highlighted the various strategies of the country in order to ensure its development, including a belief in education and science as pivot areas expected to guide the modernization and closer the nation of the most developed countries worldwide. Actions such as decentralizing the administrative structure, extend university autonomy, reorganize the universities for efficiency, effectiveness and expansion in addition to the diversification of funding sources, have been strengthened. All these points were later legislated in Higher Education Law, which was implemented on 1 January 1999, representing a new institutionalization of governance and management of Chinese higher education (ZHA, 2009).

Levin (2010) says that in the celebrations of the hundredth anniversary of Beijing University, China's president at the time, Jiang Zemin, publicly revealed the intentions of the country to pursue a wide expansion of its higher education system, and this really happened. In 1990 , only $3.4 \%$ of the age group between 18 and 22 years were allocated in higher education, in 1995 this percentage was $7.2 \%$ and in 2000 at the astounding rate of $12.5 \%$. It 
was the beginning of an unprecedented expansion in the global scenario (HAYHOE and ZHA, 2004).

However, the actual process of massification of higher education begins in 1999, with a noticeable increase in the number of enrollments, particularly in areas involving science and technology. At this time, the engineering institutions have increased their range of disciplines, with the goal of increasing the number of students and also to make some of its universities world leaders. . Looking for improve education for the twenty-first century, was defined by the following goal: increase gross participation in higher education to $11 \%$ in 2000 . Later, the goal becomes bolder, trying to achieve the indcador of $15 \%$ of young people aged $18-22$ years until 2010 since this is an internationally recognized limte higher education mass (STATE COUNCIL, 1999). The results were an increase of $47.2 \%$ in the number of new enrollments, from 1.08 million new students (1998) to 1.59 million (ZHA, 2011).

Initial results were promising and in December 2003, China announced that it is promoting the largest higher education system in the world (CHENG, 2004). The fast expansion continued until 2004, when the enrollment in higher education (considering all levels), reached the top, 20 million students, twice as 1998, since then, the growth has continued but in a more moderate way. With reference to the year 2008, if we include the informal private institutions of higher education in addittion to the regular HEIs, China reaches the surprising index of 30 million students enrolled in higher education, and these, $24.2 \%$ are in aged between 18 to 22 years, which makes the Chinese system the largest in the world in absolute numbers (ZHA, 2011). Even if you use the 2004 data, China was still in the top:

1. China: 20 million students;

2. United States: 14 million students;

3. Russia: 6.5 million students;

4. India: 5 million students; and

5. Japan: 3 million students (CHENG, 2004).

Several factors were crucial to this notorious growth and one was the incentive to initiate the operation of private higher education institutions, as the government felt that public education alone could never meet the great demand for higher education, beginning the process in the mid 90s. Data from 2002 show that more than 60000 private schools were opened in the country, among which 1,200 were of higher learning (CHENG, 2004), though not all were accredited by the Ministry of Education to issue diplomas, and in 2008 the number of accredited private institutions was 638, including 322 independent colleges. These 
institutions represented for $28 \%$ of all higher education institutions in China, with four million students.

Another important change that has helped expand the massification was the adoption of tuition fees, something that becomes official after 1997, period in which all higher education institutions start to charge fees of its students, which increased slowly to over the years. This initiative helped to expand the system because the government could no longer claim that it had no financial capacity to support the university, with an enrollment stimulated by social demand from this date.

In summary, the action of China to create a mass higher education system resulted in a fast expansion of enrollment and also a great systemic differentiation of types of institutions: traditional universities, vocational colleges, private institutions, among several others. Despite the tendency of a qualitative decrease in the universities, the debate around quality guided throughout the process of expansion. According to Hayhoe and Zha (2004), still in 1993, the government announced a number of national initiatives aimed at providing financial support to the 100 best universities in China, causing them to reach a status of "world class" in the century that would start. This project was named "Project 211".

With the celebration of the 100th anniversary of the best Chinese university, Beijing University, was created in May 1998 another project called "Project 985", with the objective of supporting even better a special group of nine universities, they are:

- Polytechnics: Tsinghua, Zhejiang, Shanghai Jiao Tong, Xi'an Jiao Tong, USTC, and Harbin Institute of Technology;

- Traditional: Beijing, Fudan, and Nanjing.

These nine universities became part of the C9 League in 2009, which is Chinese reference to U.S. Ivy League. Anyway, a greater concentration of resources is placed in Beijing and Tsinghua Universities, with the purpose of propel them to the top twenty in the world (HAYHOE and ZHA, 2010; LEVIN, 2010). In the second phase of the project, 39 universities became part of the Project 985. Regarding the values received by the universities of Project 985, the Universities of Beijing and Tsinghua each received (CN $¥ 1.8$ billion, equivalent at the time to $\$ 225$ million ). For other universities, there was a variation between CN $¥ 1.4$ billion and CN $¥ 400$ million (ZHA and HAYHOE, 2004; LEVIN, 2010).

As regards the private higher education institutions, holders of many vacancies, the Chinese government also created alternatives through student funding to support economically disadvantaged students. Actions such as scholarships, grants, student loans and study / work programs were implemented (MIN, 2008). 
In the Ministry of Education of China website, it is possible to meet some of the programs that target this type of inclusion, such as the Green Pass, which aims to ensure that all students, particularly those from poor families, have access to higher education, preventing students give up on courses for financial difficulties. In this program, the Chinese government, universities and banks have created a system of special financial assistance for needy students. Addition to the Green Pass, these students may request exemption from the registration fees, scholarships, grants, and others. The government has the responsibility to create the programs and universities and banks have a responsibility to provide the benefits (CERNET, 2013).

For being a country with continental dimensions, China is also going to invest in distance learning as a way to expand access geographically and democratize education in the country. For this reason, the intensive use of information technology in education has been promoted. Since 1999, 68 institutions of regular higher education and the University Central Radio and Television of China (CCRTVU) had a pilot project approved by the Ministry of Education with the purpose of promoting distance learning. As a result, 140 programs in 10 disciplines were developed by the end of 2002, with a total of 1,373,000 students. In order to cover the entire national territory, the 68 participating institutions have opened 2,027 learning centers outside their respective geographic locations, providing academic knowledge via CCRTVU (CERNET, 2013).

Finally, to continue prospering in regard to higher education, the Chinese government has set in July 2010 the National Panorama for the Reform and Development of Education in the Medium and Long Term (2010-2020), also known as "Planning 2020" with its focus on the aspects of improvement and quality assurance and intended to stimulate creativity among students, in addition to including a number of Chinese universities among universities recognized internationally. Inside the Planning 2020 is a Strategic Plan for Higher Education, which sets as its main priority to ensuring the quality of higher to be achieved through education:

- Development of university professors;

- Curricular development of courses;

- Creative teaching for talented students;

- Development of innovative programs for professionals;

- Transformation of Graduate Programs; and

- Deepening of Projects "211" and "985" (ZHA, 2012). 
Finally, the Chinese government has also set ambitious goals in the areas of Research and Development of the country, with the goal of applying up to $2.5 \%$ of GDP in R\& D by the year 2020 (LEVIN, 2010; IEDI, 2011) and raise the number of researchers to 4 million by the same year, especially in the areas of innovation, inside a plan known as "Plan for Medium and Long Term and Development of Talents." This plan also has a policy to attract talent from other countries to become researchers in China (something very common in the United States in recent decades), ensuring not only quantitative, but also qualitative prosperity.

\section{FINAL THOUGHTS}

This paper showed that education, especially post-secondary, is now seen as one of the keys factors to the formula of progress and economic development. For this reason, several nations have tried to advance their educational indicators not only quantitative but also in the qualitative aspect, being the responsibility of the Government the difficult task of improving these kinds of indicators.

From then on, governments should create public policies and actions for the benefit of society, working as a stabilizer to social expectations, through the influential role played by them.

Based on these assumptions, the Chinese government has developed several policies in recent years, allocating public funding to meet the needs of higher education in the country, achieving excellent results with regard to its expansion, and becoming a worldwide reference.

Therefore, a better understanding of the success of China, that until a few years ago was behind from Brazil and many other countries (in total enrolled students), is a differential for designing new policies and adapting existing policies. It is important mentioning the process of massification of higher education enrollments led by the Government, the attempt to create an emerging university model and the "post-growth" initiatives.

During the paper, we present actions such as diversification of funding for public universities, Project "211" and "985" with the purpose of making the Chinese universities with international standards and members of the small group of leading universities worldwide, the "Green Pass" as a way to ensure not only access but also permanence in the institutions, and the "Plan for Medium and Long Term and Development of Talents," which aims to increase investment in research by 2020.

Finally, we observe that the time has come to higher education in China, which for many years was forgotten. International events, globalization and the the success of various 
countries have shown the importance and the strength of this educational level, who became one of the main pillars for economic and social growth in one of the world's major powers.

\section{REFERENCES}

CARNOY, M.; RHOTEN, D. What Does Globalization Mean for Educational Change. Comparative Education Review, 46 (1), p. 1-9, 2002.

CERNET. MOE: Survey of the Educational Reform and Development in China.

China Education and Research Network. Available in:

$<$ http://www.edu.cn/Researchedu_1498/20060323/t20060323_113688.shtml $>$. Access in April 2, 2013.

CHENG, K. Expansion of higher education in China: then what? Harvard China Review, v.5, n.1, p. 82-86, 2004.

DIDRIKSSON, A. Universidad del futuro. Mexico, DF: Universidad Nacional Autónoma de México, 1993.

ERNST, D. Pathways to innovation in Asia's leading electronics-exporting countries - a framework for exploring drivers and policy implications. Int. J. Technology Management. Vol. 29, Nos. 1/2, pp.6-20. 2005.

EUROPEAN COMMISSION. Anual Growth Survey: Progress report on Europe 2020. Brussels, COM (2011) 11 - a1/2. 2011.

FREY, Klaus. A dimensão político-democrática nas teorias de desenvolvimento sustentável e suas implicações para a gestão local. Ambiente \& Sociedade, ano IV, n. 9, 2o semestre de 2001.

GIAMBIAGI, F.; ALÉM, A. C. Finanças públicas: teoria e prática no Brasil. Segunda edição. Rio de Janeiro: Campus, 2001.

GUERREIRO RAMOS, Alberto. A nova ciência das organizações: uma reconceituação da riqueza das nações. Fundação Getúlio Vargas - FGV. Rio de Janeiro. 1981.

HAYHOE, Ruth; e ZHA, Qiang. Becoming World Class: Chinese Universities Facing Globalization and Internationalization. Harvard China Review. v.5, n.1, p. 87-92. 2004.

. The Polytechnical Universities in China's Transformation. International Higher Education, Number 60 (Summer 2010), 11-13. 2010.

IGLESIAS, Enrique V. El papel del Estado y los Paradigmas Económicos en América Latina. Revista de La CEPAL, Santiago de Chile: Comisión Económica para América Latina y el Caribe (CEPAL)/ ONU, n. 90, 2006.

IEDI. A Transformação da China em Economia Orientada à Inovação. Instituto de Estudos para o Desenvolvimento Industrial. São Paulo, n. 482, 2011. 
ILON, L. Higher Education Responds to Global Economic Dynamics. In: RUST, V.; PORTNOI, L.; BAGLEY, S. (Orgs.). Higher Education, Policy and the Global Competition Phenomenon. New York: Palgrave Macmillan, 2010.

JOHNSTONE, Bruce, D. Sharing the Costs of Higher Education: Student Financial Assistance in the United Kingdom, the Federal Republic of Germany, France, Sweden and the United States. The College Board, New York, 1986.

LAZERSON, M. Higher Education and the American Dream. Success and its Discontents. Budapest: Central European University Press, 2010.

LERDA, Juan Carlos; ACQUATELLA, Jean; GÓMEZ, José Javier. Coordinación de políticas públicas: desafíos y oportunidades para una agenda fiscal-ambiental. In: ACQUATELLA, Jean; BÁRCENA, Alicia (Orgs.). Política fiscal y medio ambiente: bases para una agenda común. Santiago de Chile: Comisión Económica para América Latina y el Caribe (CEPAL)/ONU, p. 65-88. 2005.

LEVIN, Richard C. A Ascensão das Universidades Asiáticas. Revista Ensino Superior Unicamp. Campinas. Ano I, n. 2, p. 26-36. 2010.

LONGO, Carlos Alberto. Finanças Públicas: Uma Introdução. FIPE/USP, 1984.

MATIAS-PEREIRA, J. Finanças públicas: a política orçamentária no Brasil (3a ed.). São Paulo: Atlas. 2006.

MIN, Weifang. The Legacy of the Past and the Context of the Future. In Asian Universities: Historical Perspectives and Contemporary Challenges, ed. Philip Altbach and Toru Umakoshi, Johns Hopkins University Press. Baltimore, 2004.

Higher Education Financing in East Asia: Policy Implications for China. In LIN, Justin Yifu; e PLESKOVIC, Boris (Orgs). Annual World Bank Conference on Development Economics - Regional 2008: Higher Education and Development. World Bank Publications. Washington. p. 41-46. 2008.

NAOE, A. O desenho educacional que move a inovação na China. Revista Eletrônica de Jornalismo Científico, Universidade Estadual de Campinas - Unicamp, Campinas. 2012.

UN. Os Países-Membros da ONU. Organização das Nações Unidas. Available in: $<$ http://www.onu.org.br/conheca-a-onu/paises-membros/>. Access in April 18, 2013.

SAWAYA, Rubens R. Crise: um problema conjuntural ou da lógica da acumulação mundial?. Estud. av., São Paulo, v. 23, n. 66, 2009.

SILVA, C .L. Desenvolvimento sustentável: um conceito multidisciplinar. In: SILVA, C.L.; MENDES, J.T.G. (Org.). Reflexões sobre o desenvolvimento sustentável: agentes e interações sob a ótica multidisciplinar. 1. ed. Rio de Janeiro: Vozes, p. 11-40. 2005. 
STATE COUNCIL. Action plan for vitalizing education for the twenty-first century. In:

China Education Yearbook. ed. Ministry of Education of China, People's education press. Pequin, p. 107-16. 1999.

TÜNNERMANN BERNHEIM, C. La educación superior necesária para el siglo XXI. In: LOPEZ SEGRERA, F.; RIVAROLA, D.M. (Comp.). La universidad ante los desafios del siglo XXI. Asunción: Ediciones y Arte, p. 25-69. 2010.

WEI, Houkai. Decentralization and Regional Disparities in Education in China. In: Foreign Affairs Bureau CASS. Ed., Social Sciences: CASS Forum, Foreign Languages Press, p.6490, 1999.

WORLD BANK. China: Management and finance of higher education. A World Bank Country Study. The World Bank. Washington. 1986. 1997.

China: higher education reform. A country study. The World Bank. Washington.

WU, Y. The Equality of Educacional Opportunity in Chinese Higher Education. Dissertação (Mestrado Europeu em Ensino Superior). Aveiro. Secção Autónoma de Ciências Sociais, Jurídicas e Políticas, Universidade de Aveiro, 2006.

ZHA, Qiang; HAYHOE, Ruth. The Beijing Consensus and Chinese Higher Education: The Successful Stories and Looming Crisis (Apresentação). In: Ensino Superior e

Desenvolvimento: a experiência dos BRICS (Seminário Internacional). Universidade de Campinas - Unicamp, 08 de Novembro de 2008.

ZHA, Qiang. Diversification or Homogenization: How Governments and Markets Have Combined to (Re)Shape Chinese Higher Education in Its Recent Massification Process.

Higher Education, v.58 n.1, p.41-58. 2009.

China's move to mass higher education in a comparative perspective. Compare: A

Journal of Comparative and International Education, v.41, n.6, 751-768. 2011.

. The Study-Abroad Fever among Chinese Students. International Higher

Education, Number 69, (Fall 2012), 15-17. 2012.

ZHANG, Baoqing. Reforming Education in China, Higher Education Press, v. 2, p. 158-60, 1993. 